\title{
Associations Between Bullying and Depression Among Students in School Transition
}

\section{Asociaciones entre bullying y depresión entre estudiantes en transición escolar}

\section{Associações entre bullying e depressão em estudantes em transição escolar}

\author{
Jorge Luiz da Silva ${ }^{1}$ (D) Wanderlei Abadio de Oliveira ${ }^{2}$ (D) \\ André Vilela Komatsu ${ }^{3}$ (D) Marcela Almeida Zequinão ${ }^{4}$ (D) \\ Beatriz Oliveira Pereira ${ }^{5}$ (D) . Simona Carla Silvia Caravita ${ }^{6}$ (D) \\ Grace Skrzypiec $^{7}$ (D) - Marta Angélica lossi Silva ${ }^{8}$ (D)
}

Published online: 16 March 2020

(C) Associação Brasileira de Psicologia 2020

\begin{abstract}
Bullying affects the health and development of children and adolescents. This study examined the relationships between depression and students' profiles in regard to their involvement with bullying (as victim, bully, or bully-victim), among students transitioning to middle school. A total of 4086 th grade students (54.9\% girls; mean age $=11.3$ years; $\mathrm{SD}=0.62$ years) from six Brazilian public schools participated in this study. The participants completed the Aggression and Peer Victimization Scale and the Children's Depression Inventory. Data were analyzed using variance analysis (ANOVA), Spearman's correlation coefficient, and logistic regression. Bully-victim were nine times more likely to be depressive compared with students not involved with bullying $(\beta=2.246, O R=9.44$, $p=0.002)$, while victims were six times more likely $(\beta=1.843, O R=6.31, p=0.010)$. Among girls, depression was significantly correlated with all forms of bullying and victimization (physical, verbal, relational). Among boys, only verbal and relational victimization was significantly correlated with depression. This study's results contribute to understanding the relationship between depression and bullying during school transition.
\end{abstract}

\section{Resumen}

El bullying afecta la salud y el desarrollo de niños y adolescentes. Este estudio examinó las relaciones entre la depresión y los perfiles de los estudiantes con respecto a su participación

Jorge Luiz da Silva

jorge.silva@unifran.edu.br

Extended author information available on the last page of the article 
en el acoso (como víctima, acosador o víctima de acoso) entre los estudiantes que están pasando a la escuela secundaria. En este estudio participaron un total de 408 estudiantes de sexto grado $(54,9 \%$ de niñas; edad media $=11,3$ años; $\mathrm{DE}=0,62$ años $)$ de seis escuelas públicas brasileñas. Los participantes completaron la Escala de Agresión y Victimización de Pares y el Inventario de Depresión Infantil. Los datos se analizaron mediante el análisis de varianza (ANOVA), el coeficiente de correlación de Spearman y la regresión logística. Las víctimas de acoso fueron nueve veces más propensas a ser depresivas en comparación con los estudiantes que no participaron en el acoso escolar $(\beta=2.246$, OR $=9.44, p=$ $0.002)$, mientras que las víctimas tenían seis veces más probabilidades $(\beta=1.843, \mathrm{OR}=$ $6.31, p=0.010$ ). Entre las niñas, la depresión se correlacionó significativamente con todas las formas de acoso y victimización (física, verbal, relacional). Entre los varones, solo la victimización verbal y relacional se correlacionó significativamente con la depresión. Los resultados de este estudio contribuyen a comprender la relación entre la depresión y el bullying durante la transición escolar.

\section{Resumo}

O bullying afeta a saúde e o desenvolvimento de crianças e adolescentes. Este estudo examinou as relações entre depressão e os perfis de participação no bullying (vítima, agressor ou vítima-agressora) de estudantes em transição escolar. Um total de 408 estudantes do $6^{\circ}$ ano $(54,9 \%$ meninas; média de idade $=11,3$ anos; desvio-padrão $=$ 0,62 anos) de seis escolas públicas brasileiras participaram deste estudo. Os participantes responderam a Escala de Agressão e Vitimização entre Pares e o Inventário de Depressão Infantil. Os dados foram analisados mediante análise de variância (ANOVA), coeficiente de correlação de Spearman e regressão logística. Os resultados indicaram que as vítimas-agressoras foram nove vezes mais propensos a serem depressivas em comparação com os alunos não envolvidos com o bullying ( $\beta=$ $2.246, \mathrm{OR}=9,44, p=0,002)$, enquanto as vítimas eram seis vezes mais prováveis $(\beta=$ $1,843, \mathrm{OR}=6,31, \mathrm{p}=0,010)$. Entre as meninas, a depressão foi significativamente correlacionada com todas as formas de bullying e vitimização (física, verbal e relacional). Entre os meninos, apenas a vitimização verbal e relacional foi significativamente correlacionada à depressão. Os resultados deste estudo contribuem para entender a relação entre depressão e bullying durante a transição escolar.

Keywords Bullying · Violence · Victimization

Palabras clave Bullying · violencia $\cdot$ victimización

Palavras-chave Bullying, violência, vitimização por pares

Adolescence is a period involving biological, psychological, and social changes. Greater cognitive development and the search for autonomy change the way adolescents relate with their families, school, and peers (Duarte et al. 2015). These changes can be a challenge for some adolescents, leaving them vulnerable to the development of mental disorders (Rocha et al. 2013). For instance, the probability of depressive episodes occurring during adolescence increases from 5 to 20\% (Thapar et al. 2012). Due to its high prevalence, depression during adolescence is considered a public health problem, 
as well as due to its association with life-threatening behavior, such as suicide, and other potentially avoidable public health problems, such as the consumption of alcohol and tobacco (Flores-Cornejo et al. 2017). Depressive symptoms can be triggered by loss, conflict, violence, frustration, or traumatic events (Reijntjes et al. 2011). Because peer relationships are highly valued during adolescence, being a target of bullying at school may predispose adolescents to depression (Pigozi and Machado 2015).

Bullying is a type of violence among peers characterized by intention, repetitiveness, and imbalance of power between victims and bullies (Oliveira et al. 2018; Olweus 2013). In Brazil, approximately $28 \%$ of students have perpetrated bullying or have been bullied in terms of physical (e.g., punching, kicking, pushing), verbal (e.g., calling/being called names, cursing at/being cursed at), or/and relational aggression (e.g., socially isolating the victim/ being socially isolated, spreading rumors/subject of rumors) (Mello et al. 2017; Sampaio et al. 2015; Silva et al. 2016a). Some studies have provided evidence that bullying is more frequent during school transitions, especially from elementary to middle school, because students must relate with a larger number of unfamiliar classmates and establish new social groups (Silva et al. 2016b; Olweus 2013). In this period, bullying can serve as a means of self-assertion or to attain greater social status and popularity (Silva et al. 2016b).

Additionally, the transition to middle school coincides with the beginning of adolescence, so there is a greater likelihood of students developing depressive symptoms (Kaltiala-Heino and Fröjd 2011). An increase in the number of bullying occurrences during school transition may aggravate difficulties faced by adolescents, predisposing them to depression (Kaltiala-Heino and Fröjd 2011). The scientific literature has already reported a relationship between bullying and depression (Reijntjes et al. 2010, 2011). One study addressing 2464 Norwegian adolescents found a moderate association between being bullied and depressive symptoms (Undheim et al. 2016). Bullies also face the same problem as reported by a cohort study addressing the mental health of Finnish adolescents (Kaltiala-Heino et al. 2010). In general, bullied girls present more depressive symptoms while male bullies are also at a greater risk of presenting depressive symptoms (Kaltiala-Heino et al. 2010).

Even though some studies report the negative consequences of being involved with bullying (Kaltiala-Heino et al. 2010; Reijntjes et al. 2010, 2011; Undheim et al. 2016), there are gaps in the Brazilian literature concerning the relationship between this phenomenon and depression during adolescence (Forlim et al. 2014). Hence, this study's objective was to identify associations between depression and involvement with bullying (as a victim, bully, or bully-victim) among boys and girls transitioning to middle school.

\section{Method}

\section{Participants}

This was a cross-sectional and correlational study (Neuman 2014). A total of 408 6th grade students (first year of the equivalent to middle school in Brazil) attending six public schools, aged from 10 to 12 years, 11.3 years on average ( $S D=0.62$ years) participated in this study. Two hundred and twenty-four (54.9\%) were girls and 184 (45.1\%) were boys. In regard to academic achievement, $30(7.4 \%)$ students failed to pass a school grade at least once. Most students $(64.2 \%, n=262)$ belonged to the socioeconomic classes B2 and $\mathrm{C} 1$ of the Brazilian 
Economic Classification Criteria; that is, they belonged to families with a total income between R \$ 2705.00 (U\$ 711.00) and R \$ 4852.00 (U\$ 1276.00), which is true for 39.5\% of all Brazilian families (Associação Brasileira de Empresas de Pesquisa 2010). In terms of race, the students self-reported being of mixed race $(46.1 \%, n=188)$, Caucasian $(40.9 \%, n=$ $167)$, Afro-descendant $(6.1 \%, n=25)$, Asian-descendant $(4.9 \%, n=20)$, and indigenous $(2.0 \%, n=8)$.

\section{Measures}

Aggression and Peer Victimization Scale (Cunha et al. 2011) This measure was used to assess perpetrated and experienced bullying and to establish students' profile as victims, bullies, bully-victims, or not involved. The Aggression and Peer Victimization Scale consists of 18 items presenting short statements concerning bullying behavior: 10 concerning physical, verbal, or relational bullying and 8 items concerning physical, verbal, or relational victimization. Examples of the items are the following: "I pushed, punched, and/or kicked other students" (physical bullying); "I was pushed, punched and/or kicked by other students" (physical victimization); "I offended colleagues through insults"; "I put nickname colleagues they did not like"; "I excluded other students from groups or games"; "Other students excluded me from groups and/or games." The answers are provided on a 5-point Likert scale (never; almost never; sometimes; almost always; always). The EVAP can be applied among students aged between 10 and 18 years old. Psychometric analyses indicate adequate to good internal consistency for victimization and bullying, with Cronbach's alpha ranging between 0.72 and 0.81 .

Children's Depression Inventory (CDI) (Gouveia et al. 1995) This inventory was developed by Kovacs (1983) and adapted for the Brazilian population by Gouveia et al. (1995). It is composed of 20 items clustered into five categories of depressive symptoms: anhedonia, negative self-esteem, interpersonal difficulties, negative mood, and inefficacy. Each of the items has three options for responses, among which the child or adolescent chooses one that best describes the way they have felt in the last 2 weeks, from $a=$ having no symptoms to $b$ = having symptoms to $\mathrm{c}=$ having severe symptoms, for instance (a) I sometimes get sad, (b) I often get sad, and (c) I am always sad. The items are scored zero (answer a), 1 (answer b), or 2 points (answer c). The maximum possible score is 40 points. The cutoff point for clinical depression is equal to or higher than 17 points. The CDI can be applied to children and adolescents aged between 7 and 17 years old. It presents good internal consistency with a Cronbach's alpha equal to 0.81 .

Sociodemographic Questionnaire This questionnaire was prepared for this research with the objective of collecting information about sex, age, and socioeconomic level. The socioeconomic level, specifically, was evaluated according to the classification proposed by the Brazilian Association of Research Companies (ABEP), which divides individuals into classes from $\mathrm{A}$ (rich) to $\mathrm{E}$ (poor). This classification takes into account the education of the head of the family and the possession of real goods (ABEP 2010). 


\section{Procedures}

Data were collected between February and March 2015 among 18 6th grade classrooms from six public schools located in Ribeirão Preto, SP, Brazil. The schools composed a convenience sample. A total of 522 students were invited to participate in the study and received clarification regarding the study's objectives and data collection procedures. A total of 408 students agreed to participate and signed a consent form and presented free and informed consent forms signed by their parents or legal guardians, so that the rate of participation was $78.1 \%$. Data were collected during regular school hours. The researchers explained how to complete the two instruments (Aggression and Peer Victimization Scale and Children's Depression Inventory) and were available to clarify any doubts during application. Approximately $30 \mathrm{~min}$ was the time required in each class to provide instructions and complete the instruments.

\section{Data analysis}

In order to establish the profile of students in terms of their involvement with bullying, cluster analysis was performed considering the answers provided to the Aggression and Peer Victimization Scale, according to Ward's hierarchical method, which tends to result in approximately equal-sized groupings. Four groups resulted: (1) not involved (low frequency of victimization and low frequency of bullying); (2) victims (high frequency of victimization and low or moderate frequency of bullying); (3) bullies (high frequency of bullying and low or moderate frequency of victimization); and (4) bully-victims (high frequency of victimization and high frequency of bullying). Students who obtained a score equal to or higher than 17 in the Children's Depression Inventory were considered depressive.

Analyses of variance (ANOVA) were used to identify differences in dependent variables according to an individual's involvement with bullying (victims, bullies, bully-victims, or non-involvement), followed by Bonferroni's post-test to identify groups with statistical differences. Spearman's correlation coefficient was calculated to examine the relationships between role and depression variables. ANOVA was chosen because it is a robust method, even in cases where the normality of the variables is not observed, considering the high number of observations (all groups with more than 50 participants). Spearman's statistic was preferred for being less restrictive than Pearson's, once no purely linear relationship was expected between the variables (Hauke and Kossowski 2011). Association between depression and bullying profiles was analyzed via logistic regression. All analyses were performed using the SPSS 22. A significance level of $5 \%(p<0.05)$ was used in all analyses.

\section{Ethical Considerations}

The study project was submitted to and approved by the Institutional Review Board at the University of São Paulo (CAEE: 39462414.0.0000.5393, Protocol No. 18/2015). The Regional Board of Education and the schools' principals also authorized the study. The parents or legal guardians consented to the participation of students by signing free and informed consent forms; the students also signed a consent form and they could leave the study at any time. Recommendations and guidelines provided by Resolutions 466/2012 and 510/2016 of the Brazilian National Council of Health were complied with. 


\section{Results}

In regard to bullying, the sample $(n=408)$ was classified as follows: not involved (41.9\%), bullies (33.1\%), victims (14.5\%), and bully-victims $(10.5 \%)$. The results concerning depression are presented in Table 1.

The results indicate that $5.4 \%$ of the participants were classified with depression. The results presented in Table 1 indicate the group of bully-victims presented the highest percentage of depression (14\%), while the group of non-involved individuals presented the lowest percentage $(1.8 \%)$. Among the 22 individuals with depression, $59.1 \%$ were girls. The group of bully-victims presented the highest number of depressive girls $(83.3 \%)$, while the group of bullies presented the highest number of depressive boys $(57.1 \%)$. Table 2 presents a comparison between students not involved with bulling and those involved with bullying (victim, bully-victim, or bully) in regard to depression variables.

Table 2 reports the results of the bully group comparison (ANOVA test). Significant differences were found in the means concerning total depression among boys and girls. Bonferroni's post-test indicated that the significant difference in regard to total depression among boys occurred only between the group of victims and those not involved with bullying $(p=0.01)$. For the girls, difference with statistical significance was found between the bully-victims and the groups of non-involved students $(p<0.001)$ and bullies $(p<0.05)$, as well as between the group of victims and the group of non-involved students $(p<0.05)$.

In regard to anhedonia, among girls, the bully-victims and those not involved with bullying significantly differed from each other (Bonferroni's post-test, $p<0.01$ ), while the mean scores did not differ among boys. In terms of inefficacy, the mean scores only differed significantly among boys, with victims and individuals not involved with bullying $(p<0.01)$, as well as between bully-victims and non-involved students $(p<0.05)$. The group of girls presented significant differences in terms of self-esteem. These differences were found between bully-victims and the groups of bullies $(p<0.01)$ and those not involved with bullying $(p<0.001)$, as well as between victims and those not involved with bullying $(p<0.01)$. Negative mood scores significantly differed among girls, with bully-victims significantly differing from non-involved students (Bonferroni's post-test, $p<0.01$ ). In terms of interpersonal problems, significant differences were found neither among girls nor boys (Table 2).

Table 1 Students with depression according to gender and bullying profile

\begin{tabular}{|c|c|c|c|c|c|c|c|c|}
\hline & \multicolumn{2}{|c|}{ Victim $(n=59)$} & \multicolumn{2}{|c|}{ Bully-victim $(n=43)$} & \multicolumn{2}{|c|}{ Bully ( $n=135)$} & \multicolumn{2}{|c|}{ Not involved $(n=171)$} \\
\hline & $n$ & $\%$ & $n$ & $\%$ & $n$ & $\%$ & $n$ & $\%$ \\
\hline \multicolumn{9}{|c|}{ Depression } \\
\hline Yes & 6 & 10.2 & 6 & 14.0 & 7 & 5.2 & 3 & 1.8 \\
\hline No & 53 & 89.8 & 37 & 86.0 & 128 & 94.8 & 168 & 98.2 \\
\hline \multicolumn{9}{|c|}{ Depression according to gender } \\
\hline Boys & 3 & 50.0 & 1 & 16.7 & 4 & 57.1 & 1 & 33.3 \\
\hline Girls & 3 & 50.0 & 5 & 83.3 & 3 & 42.9 & 2 & 66.7 \\
\hline
\end{tabular}


Table 2 Comparison among students involved with bullying and not involved with bullying in regard to depression variables

\begin{tabular}{|c|c|c|c|c|c|c|c|c|c|c|}
\hline & \multicolumn{2}{|c|}{ Victim $(n=59)$} & \multicolumn{2}{|c|}{ Bully-victim $(n=43)$} & \multicolumn{2}{|c|}{ Bully $(n=135)$} & \multicolumn{2}{|c|}{ Not involved $(n=171)$} & \multicolumn{2}{|c|}{ ANOVA } \\
\hline & Mean & $S D$ & Mean & $S D$ & Mean & $S D$ & Mean & $S D$ & $F$ & $p$ \\
\hline \multicolumn{11}{|c|}{ Total depression } \\
\hline Boys & $8.6^{\mathrm{a}}$ & 5.8 & 7.4 & 5.2 & 6.3 & 5.5 & $4.5^{\mathrm{b}}$ & 4.5 & 4.2 & 0.007 \\
\hline Girls & 8.2 & 6.1 & $10.7^{\mathrm{a}}$ & 8.0 & $6.8^{\mathrm{b}}$ & 5.2 & $5.2^{\mathrm{b}}$ & 4.7 & 7.4 & 0.000 \\
\hline \multicolumn{11}{|c|}{ Anhedonia } \\
\hline Boys & 2.8 & 2.2 & 2.2 & 2.0 & 1.9 & 1.9 & 1.5 & 1.8 & 2.5 & 0.065 \\
\hline Girls & 2.8 & 2.3 & $3.6^{\mathrm{a}}$ & 3.0 & 2.2 & 2.0 & $1.9^{\mathrm{b}}$ & 1.9 & 5.1 & 0.002 \\
\hline \multicolumn{11}{|c|}{ Inefficacy } \\
\hline Boys & $2.1^{\mathrm{a}}$ & 1.1 & $1.9^{\mathrm{a}}$ & 1.4 & 1.4 & 1.4 & $1.0^{\mathrm{b}}$ & 1.1 & 5.4 & 0.001 \\
\hline Girls & 1.7 & 1.3 & 2.1 & 1.4 & 1.7 & 1.4 & 1.4 & 1.4 & 2.0 & 0.119 \\
\hline \multicolumn{11}{|c|}{ Self-esteem } \\
\hline Boys & 1.5 & 1.7 & 1.5 & 1.3 & 1.2 & 1.6 & 0.9 & 1.3 & 1.6 & 0.203 \\
\hline Girls & $1.6^{\mathrm{ab}}$ & 1.7 & $2.3^{\mathrm{a}}$ & 1.9 & $1.1^{\mathrm{b}}$ & 1.4 & $0.7^{\mathrm{c}}$ & 1.0 & 10.6 & 0.000 \\
\hline \multicolumn{11}{|c|}{ Negative mood } \\
\hline Boys & 1.0 & 1.8 & 0.8 & 1.0 & 0.7 & 1.3 & 0.3 & 0.7 & 2.4 & 0.072 \\
\hline Girls & 1.2 & 1.6 & $1.6^{\mathrm{a}}$ & 2.1 & 0.9 & 1.4 & $0.5^{\mathrm{b}}$ & 1.1 & 4.9 & 0.003 \\
\hline \multicolumn{11}{|c|}{ Interpersonal problems } \\
\hline Boys & 1.1 & 1.2 & 1.0 & 1.2 & 1.1 & 1.0 & 0.7 & 1.0 & 2.3 & 0.084 \\
\hline Girls & 0.9 & 0.8 & 1.1 & 1.2 & 0.9 & 0.9 & 0.7 & 0.9 & 1.0 & 0.390 \\
\hline
\end{tabular}

Groups that differ significantly $(p<0.05)$ at Bonferroni's post-test are reported with different apical letters

Table 3 presents the correlations among types of victimization and bullying and depression variables.

Among boys, verbal victimization was significantly correlated with all the depression variables. A significant correlation was also found between relational victimization and total depression, anhedonia, inefficacy, and negative mood. In regard to bullying, verbal bullying was significantly correlated with inefficacy, negative mood, and interpersonal problems. All significant correlations for boys were positive, indicating that the higher the level of victimization or bullying, the higher the level of depression and vice versa.

All the significant correlations were also positive among girls. The three types of victimization and the three types of bullying were significantly correlated with total depression and self-esteem. Additionally, both physical victimization and verbal victimization were significantly correlated with anhedonia, inefficacy, and negative mood. Relational victimization was significantly correlated with total depression, anhedonia, inefficacy, and self-esteem. A significant correlation was also found between physical and total depression, inefficacy, and self-esteem, as well as between bullying and total depression, anhedonia, inefficacy, self-esteem, and negative mood. Relational bullying was correlated with total depression, anhedonia, self-esteem, and interpersonal problems.

Table 4 shows the results of logistic regression for gender and bullying profiles as predictors of being depressed (clinical group). 
Table 3 Correlations between depression variables and types of bullying and victimization

\begin{tabular}{|c|c|c|c|c|c|c|}
\hline & $\begin{array}{l}\text { Physical } \\
\text { victimization }\end{array}$ & $\begin{array}{l}\text { Verbal } \\
\text { victimization }\end{array}$ & $\begin{array}{l}\text { Relational } \\
\text { victimization }\end{array}$ & $\begin{array}{l}\text { Physical } \\
\text { bullying }\end{array}$ & $\begin{array}{l}\text { Verbal } \\
\text { bullying }\end{array}$ & $\begin{array}{l}\text { Relational } \\
\text { bullying }\end{array}$ \\
\hline \multicolumn{7}{|c|}{ Total depression } \\
\hline Boys & 0.122 & $0.274 * *$ & $0.240^{*}$ & 0.034 & 0.140 & 0.050 \\
\hline Girls & $0.218 * *$ & $0.237 * *$ & $0.233 * *$ & $0.176^{* * *}$ & $0.259 * *$ & $0.182 * *$ \\
\hline \multicolumn{7}{|c|}{ Anhedonia } \\
\hline Boys & 0.091 & $0.185 *$ & $0.158 *$ & 0.002 & 0.013 & 0.015 \\
\hline Girls & $0.150 *$ & $0.172 * *$ & $0.175^{* * *}$ & 0.113 & $0.198^{* *} *$ & $0.155 *$ \\
\hline \multicolumn{7}{|c|}{ Inefficacy } \\
\hline Boys & 0.085 & $0.270 *$ & $0.253 *$ & -0.023 & $0.149^{*}$ & 0.107 \\
\hline Girls & $0.178 * *$ & $0.149^{*}$ & $0.163^{*}$ & $0.156^{*}$ & $0.228^{* *}$ & 0.086 \\
\hline \multicolumn{7}{|c|}{ Self-esteem } \\
\hline Boys & 0.108 & $0.177 *$ & 0.126 & -0.055 & 0.024 & -0.063 \\
\hline Girls & $0.235 * *$ & $0.310 * *$ & $0.246^{* *}$ & $0.182 * *$ & $0.212 * *$ & $0.147 *$ \\
\hline \multicolumn{7}{|c|}{ Negative mood } \\
\hline Boys & 0.059 & $0.196 * *$ & $0.227 * *$ & 0.107 & $0.174 *$ & 0.116 \\
\hline Girls & $0.201 * *$ & $0.188 * *$ & 0.122 & 0.125 & $0.021 * *$ & 0.062 \\
\hline \multicolumn{7}{|c|}{ Interpersonal problems } \\
\hline Boys & 0.077 & $0.151 *$ & 0.129 & 0.107 & $0.201 *$ & 0.041 \\
\hline Girls & 0.033 & 0.076 & 0.098 & 0.116 & 0.093 & $0.149 *$ \\
\hline
\end{tabular}

$* * p<0.001, * p<0.05$

No significant associations were found between depression and gender or being a bully. Bully-victims were nine times more likely to be depressive in comparison with individuals not involved with bullying, while victims were six times more likely to be depressive (Table 4).

\section{Discussion}

This study's sample presented a rate of $58.1 \%$ of students involved with bullying, twice the national mean of $28 \%$ (Mello et al. 2017), though similar to the results reported by Brazilian studies using non-representative samples (Bandeira and Hutz 2012; Souza

Table 4 Odds ratio using depression as dependent variable

\begin{tabular}{lrlll}
\hline Variables & \multicolumn{1}{l}{$\mathrm{B}$} & ORa & $95 \% \mathrm{CI}$ & \multicolumn{1}{c}{$p$} \\
\hline Gender & -0.276 & 0.76 & $(0.30-1.87)$ & 0.540 \\
Bully-victims* & 2.246 & 9.44 & $(2.24-39.8)$ & 0.002 \\
Victim* & 1.843 & 6.31 & $(1.52-26.15)$ & 0.010 \\
Bully* & 1.173 & 3.23 & $(0.81-12.9)$ & 0.096 \\
\hline
\end{tabular}

*Not-involved group as comparison group. ORa adjusted odds ratio; 95\% CI confidence interval of $95 \%$ 
et al. 2015). This may have occurred because rates of bullying tend to be greater during the beginning of adolescence, and likewise in the 6th grade due to school transition (Silva et al. 2016b; Olweus 2013). This high prevalence of bullying may increase the likelihood of students presenting depressive symptomatology due to bullying that they experience from or perpetrate against their school peers. The prevalence of depression in this study for victims, bullies, and bully-victims was 5.4\% and for the total sample was $3.9 \%$, findings similar to those reported by another Brazilian study (Forlim et al. 2014), though below the average rates of $10 \%$ reported by studies developed in other countries such as Cyprus (Sokratis et al. 2017), South Korea (Shin et al. 2008), Spain (Davanzo et al. 2004), and Italy (Frigerio et al. 2001). Differences in the results may be due to cultural differences, different cutoff points for depression (17 or 19 points), and the two existing CDI versions (20 or 27 items) (Giannakopoulos et al. 2009). According to previous studies (Fekkes et al. 2006; Forlim et al. 2014), the results indicate that girls were classified as depressive more frequently than boys.

Depression was more prevalent among bully-victims and victims, who were respectively nine and six times more likely to become depressive when compared with students not involved with bullying. This study is consistent with previous studies. For instance, Fekkes and cols. (2006) found that children aged between 9 and 11 years old who experienced bullying were significantly more likely to develop depression. The study by Duarte et al. (2015) addressing adolescents aged between 12 and 18 years old reports that victimization was associated with increased frequency of depressive symptoms. One meta-analysis has also provided evidence that depression was a consequence of victimization (Reijntjes et al. 2011). One potential explanation is that children and adolescents who are victims of bullying assign the causes of victimization to themselves; that is, they blame themselves and their personal characteristics, instead of seeking adaptive coping strategies, such as asking teachers for help, for instance (Henrich and Shahar 2014). Other studies confirm this association between peer victimization and severe forms of self-criticism and self-directed anger and contempt (Cunha et al. 2012; Gilbert and Irons 2009). Additionally, the correlation found in this study between depression and verbal and relational victimization for both girls and boys suggests that victims may blame themselves for the name-calling and cursing of which they are targets and negatively assess themselves, possibly developing an internal process of shame defined as self-criticism (Gilbert and Irons 2009). Gilbert et al. (2004) show that self-criticism leads to depressive symptoms. This result shows that all types of bullying are harmful, rather than only physical bullying, which adults usually consider to be more severe because it leaves visible damage (Silva et al. 2013).

There may be a reciprocal association between victimization and depression, as depressive children and adolescents interpret non-hostile interactions as bullying, which inflates the estimates of victimization. They may also respond aggressively and encourage or aggravate the aggression they experience (Kaltiala-Heino and Fröjd 2011), especially if they present low levels of social skills. Hence, depression and experienced bullying may influence each other and remain stable over time. Reijntjes et al. (2010) found that victimization increases the risk of depressive symptoms, which in turn increased the risk of later victimization. This situation may be even more severe for bully-victims, as this study's results suggest, as these individuals present high levels of victimization and bullying and also experience more behavioral and emotional problems (Silva et al. 2016b). Bully-victims were five times more likely to 
experience depression than students not involved with bullying in a study addressing 6th to 9th grade students (Forlim et al. 2014). This study also shows that female bullyvictims are more likely to experience depression, more specifically, nine times more likely than students not involved with bullying.

In regard to the depression subscales, the four profiles of boys differ in terms of inefficacy and the four profiles of girls differed in terms of anhedonia, self-esteem, and negative mood. These differences between gender groups coincide with evidence that girls generally report mood problems more frequently, while boys more frequently report behavioral symptoms (Camodeca and Goossens 2005). Correlation was found between bullying and total depression only for girls, indicating that female bullies are at a greater risk of showing depression (Kaltiala-Heino and Fröjd 2011). Even though some studies have also identified higher levels of depressive symptomatology related to bullying (Camodeca and Goossens 2005; Forlim et al. 2014), this result contradicts most studies addressing bullying and depression, which report that victimization is related to major internalization problems (Kaltiala-Heino and Fröjd 2011). The correlation among girls between depression and verbal bullying is in agreement with another study reporting similar results (Vuijk et al. 2007).

Additionally, the period of school transition may be a factor contributing to the depressive symptomatology participants present. Changes in the school cycle associated with the biological changes experienced in the beginning of adolescence and longer periods spent with peers may render adolescents more vulnerable to victimization or even to the adoption of behaviors that put them in a vulnerable condition (e.g., shyness and isolation) (Forlim et al. 2014).

This study presents some limitations. First, data do not allow for the establishment of cause and effect. Because depression can be either a cause or a consequence of bullying (Reijntjes et al. 2011), future studies using longitudinal designs are needed to confirm whether depression renders students more susceptible to perpetrating and suffering bullying or depression is a consequence of bullying. Secondly, the results are based on self-reported data, which may present a social desirability bias. Studies may obtain more reliable results if other informants are used, such as friends and teachers, though self-report instruments remain important tools to measure internalizing problems such as depression and bullying because an individual's self-perception, as a victim or bully, may affect his/her emotional condition, generating anxiety, stress, shame, or guilt, even when it is a false perception (Kaltiala-Heino and Fröjd 2011). Thirdly, the large number of students $(21.9 \%)$ who refused to participate in the study may represent a selection bias; perhaps those students more intensely involved with bullying were less willing to participate in the study. Finally, the results concerning depression may be related not only to bullying but also to other problems related to the school transition. This limitation may be overcome if future studies address other aspects, such as school climate, academic performance, and social isolation among students during school transition.

Despite these limitations, results from this study contribute to understanding the relationship between depression and bullying during school transition. Regardless of the direction of causality, these two problems should be prevented during childhood and adolescence by addressing depression in school programs intended to prevent bullying and, on a clinical level, when children and adolescents report being involved with bullying, whether as a victim or a bully. The prevention, early identification, and 
efficient treatment of depressive symptoms may impede or decrease involvement of young individuals with school bullying.

Compliance with Ethical Standards The study project was submitted to and approved by the Institutional Review Board at the University of São Paulo (CAEE: 39462414.0.0000.5393, Protocol No. 18/ 2015). The Regional Board of Education and the schools' principals also authorized the study. The parents or legal guardians consented to the participation of students by signing free and informed consent forms; the students also signed a consent form and they could leave the study at any time.

\section{References}

Associação Brasileira de Empresas de Pesquisa. (2010). Critério de classificação econômica [Criteria for economic classification]. Retrieved from http://www.abep.org/criterioBrasil.aspx

Bandeira, C. M., \& Hutz, C. S. (2012). Bullying: Prevalence, implications and gender differences. Psicologia Escolar e Educacional, 16(1), 35-44. https://doi.org/10.1590/S1413-85572012000100004.

Camodeca, M., \& Goossens, F. A. (2005). Aggression, social cognitions, anger and sadness in bullies and victims. The Journal of Child Psychology and Psychiatry, 46(2), 186-197. https://doi.org/10.1111/j.14697610.2004.00347.x.

Cunha, J. M., Weber, L. N. D., \& Steiner Neto, P. (2011). Escala de Vitimização e Agressão entre Pares [Aggression and Peer Victimization Scale]. In L. N. D. Weber \& M. A. Dessen (Eds.), Pesquisando a familia. Instrumentos para coleta e análise de dados [Researching family. Instruments for data collection and analysis] (pp. 103-114). Juruá: Curitiba.

Cunha, M., Matos, M., Faria, D., \& Zagalo, S. (2012). Shame memories and psychopathology in adolescence: the mediator effect of shame. International Journal of Psychology and Psychological Therapy, 12(2), 203-218.

Davanzo, P., Kerwin, L., Nikore, V., Esparza, C., Forness, S., \& Murrelle, L. (2004). Spanish translation and reliability testing of the Child Depression Inventory. Child Psychiatry and Human Development, 35(1), 75-92. https://doi.org/10.1023/B:CHUD.0000039321.56041.cd.

Duarte, C., Pinto-Gouveia, J., \& Rodrigues, T. (2015). Being bullied and feeling ashamed: Implications for eating psychopathology and depression in adolescent girls. Journal of Adolescence, 44, 259-268. https://doi.org/10.1016/j.adolescence.2015.08.005.

Fekkes, M., Pijpers, F. I., Fredriks, A. M., Vogels, T., \& Verloove-Vanhorick, S. P. (2006). Do bullied children get ill, or do ill children get bullied? A prospective cohort study on the relationship between bullying and health-related symptoms. Pediatrics, 117(5), 1568-1574. https://doi.org/10.1542/peds.2005-0187.

Flores-Cornejo, F., Kamego-Tome, M., Zapata-Pachas, M. A., \& Alvarado, G. F. (2017). Association between body image dissatisfaction and depressive symptoms in adolescents. Brazilian Journal of Psychiatry, 39(4), 316-322. https://doi.org/10.1590/1516-4446-2016-1947.

Forlim, B. G., Stelko-Pereira, A. C., \& Williams, L. C. d. A. (2014). Associations between bullying and depressive symptoms in elementary students. Estudos de Psicologia (Campinas), 31(3), 367-375. https://doi.org/10.1590/0103-166x2014000300005.

Frigerio, A., Pesenti, S., Molteni, M., Snider, J., \& Battaglia, M. (2001). Depressive symptoms as measured by the CDI in a population of northern Italian children. European Psychiatry, 16(1), 33-37. https://doi. org/10.1016/S0924-9338(00)00533-2.

Giannakopoulos, G., Kazantzi, M., Dimitrakaki, C., Tsiantis, J., Kolaitis, G., \& Tountas, Y. (2009). Screening for children's depression symptoms in Greece: the use of the Children's Depression Inventory in a nationwide school-based sample. European Child \& Adolescent Psychiatry, 18(8), 485-492. https://doi. org/10.1007/s00787-009-0005-z.

Gilbert, P., \& Irons, C. (2009). Shame, self-criticism, and self-compassion in adolescence. In N. Allen (Ed.), Psychopathology in adolescence. Cambridge: Cambridge University Press.

Gilbert, P., Clarke, M., Hempel, S., Miles, J. N., \& Irons, C. (2004). Criticizing and reassuring oneself: an exploration of forms, styles and reasons in female students. British Journal of Clinical Psychology, 43(1), 31-50. https://doi.org/10.1348/014466504772812959. 
Gouveia, V. V., Barbosa, G. A., de Almeida, H. J. F., \& de Andrade Gaião, A. (1995). Children's Depression Inventory-CDI: adaptation study with students of João Pessoa. Jornal Brasileiro de Psiquiatria, 44(7), 345-349.

Hauke, J., \& Kossowski, T. (2011). Comparison of values of Pearson's and Spearman's correlation coefficient on the same sets of data. Quaestiones Geographicae, 30(2), 87-93. https://doi.org/10.2478/v10117-0110021-1.

Henrich, C. C., \& Shahar, G. (2014). Moderators of the effect of peer victimization during fifth grade on subsequent symptoms of (anxious) depression: the roles of engagement in bullying and baseline symptomatology. Prevention Science, 15(6), 888-896. https://doi.org/10.1007/s11121-013-0456-9.

Kaltiala-Heino, R., \& Fröjd, S. (2011). Correlation between bullying and clinical depression in adolescent patients. Adolescent Health, Medicine and Therapeutics, 2, 37-44. https://doi.org/10.2147/AHMT. $\mathrm{S} 11554$.

Kaltiala-Heino, R., Frojd, S., \& Marttunen, M. (2010). Involvement in bullying and depression in a 2-year follow-up in middle adolescence. European Child \& Adolescent Psychiatry, 19(1), 45-55. https://doi. org/10.1007/s00787-009-0039-2.

Kovacs, M. (1983). The Children's Depression Inventory: a self-rated depression scale for school-aged youngsters. Pittsburg: University of Pittsburg.

Mello, F. C. M., Silva, J. L., Oliveira, W. A., Prado, R. R., Malta, D. C., \& Silva, M. A. I. (2017). The practice of bullying among Brazilian schoolchildren and associated factors, National School Health Survey 2015. Ciência \& Saúde Coletiva, 22(9), 2939-2948. https://doi.org/10.1590/1413-81232017229.12762017.

Neuman, W. L. (2014). Social research methods: qualitative and quantitative approaches (7th ed.). London: Pearson Education.

Oliveira, W. A., Silva, J. L., Braga, I. F., Romualdo, C., Caravita, S. C. S., \& Silva, M. A. I. (2018). Ways to explain bullying: dimensional analysis of the conceptions held by adolescents. Ciência \& Saúde Coletiva, 23(3), 751-761. https://doi.org/10.1590/1413-81232018233.10092016.

Olweus, D. (2013). School bullying: development and some important challenges. Annual Review of Clinical Psychology, 9(1), 751-780. https://doi.org/10.1146/annurev-clinpsy-050212-185516.

Pigozi, P. L., \& Machado, A. L. (2015). Bullying during adolescence in Brazil: an overview. Ciência \& Saúde Coletiva, 20(11), 3509-3522. https://doi.org/10.1590/1413-812320152011.05292014.

Reijntjes, A., Kamphuis, J. H., Prinzie, P., \& Telch, M. J. (2010). Peer victimization and internalizing problems in children: a meta-analysis of longitudinal studies. Child Abuse \& Neglect, 34(4), 244-252. https://doi. org/10.1016/j.chiabu.2009.07.009.

Reijntjes, A., Kamphuis, J. H., Prinzie, P., Boelen, P. A., van der Schoot, M., \& Telch, M. J. (2011). Prospective linkages between peer victimization and externalizing problems in children: a meta-analysis. Aggressive Behavior, 37(3), 215-222. https://doi.org/10.1002/ab.20374.

Rocha, T. B., Zeni, C. P., Caetano, S. C., \& Kieling, C. (2013). Mood disorders in childhood and adolescence. Brazilian Journal of Psychiatry, 35, 22-31. https://doi.org/10.1590/1516-4446-2013-S106.

Sampaio, J. M. C., Santos, G. V., Oliveira, W. A., Silva, J. L., Medeiros, M., \& Silva, M. A. I. (2015). Emotions of students involved in cases of bullying. Texto \& Contexto - Enfermagem, 24(2), 344-352. https://doi.org/10.1590/0104-07072015003430013.

Shin, Y. M., Cho, H., Lim, K. Y., \& Cho, S. M. (2008). Predictors of self-reported depression in Korean children 9 to 12 years of age. Yonsei Medical Journal, 49(1), 37-45. https://doi.org/10.3349 /ymj.2008.49.1.37.

Silva, J. L., Oliveira, W. A., Bazon, M. R., \& Cecílio, S. (2013). Bullying na sala de aula: percepção e intervenção de professores. Arquivos Brasileiros de Psicologia, 65(1), 121-137.

Silva, J. L., Oliveira, W. A., Bono, E. L., Dib, M. A., Bazon, M. R., \& Silva, M. A. I. (2016a). Associações entre Bullying Escolar e Conduta Infracional: Revisão Sistemática de Estudos Longitudinais. Psicologia: Teoria e Pesquisa, 32(1), 81-90. https://doi.org/10.1590/0102-37722016012241081090.

Silva, J. L., Oliveira, W. A., Braga, I. F., Farias, M. S., Silva Lizzi, E. A., Gonçalves, M. F. C., et al. (2016b). The effects of a skill-based intervention for victims of bullying in Brazil. International Journal of Environmental Research and Public Health, 13(11), 1042. https://doi.org/10.3390/ijerph13111042.

Sokratis, S., Christos, Z., Despo, P., \& Maria, K. (2017). Prevalence of depressive symptoms among schoolchildren in Cyprus: a cross-sectional descriptive correlational study. Child and Adolescent Psychiatry and Mental Health, 11, 7-7. https://doi.org/10.1186/s13034-017-0145-8.

Souza, J. M., Silva, J. P., \& Faro, A. (2015). Bullying and homophobia: theoretical and empirical approaches. Psicologia Escolar e Educacional, 19(2), 289-298. https://doi.org/10.1590/2175-3539/2015/0192837.

Thapar, A., Collishaw, S., Pine, D. S., \& Thapar, A. K. (2012). Depression in adolescence. The Lancet, 379(9820), 1056-1067. https://doi.org/10.1016/S0140-6736(11)60871-4. 
Undheim, A. M., Wallander, J., \& Sund, A. M. (2016). Coping strategies and associations with depression among 12-to 15-year-old Norwegian adolescents involved in bullying. Journal of Nervous and Mental Disease, 204(4), 274-279. https://doi.org/10.1097/NMD.0000000000000474.

Vuijk, P., van Lier, P. A., Crijnen, A. A., \& Huizink, A. C. (2007). Testing sex-specific pathways from peer victimization to anxiety and depression in early adolescents through a randomized intervention trial. Journal of Affective Disorders, 100(1), 221-226. https://doi.org/10.1016/j.jad.2006.11.003.

\section{Affiliations}

Jorge Luiz da Silva ${ }^{1}$ - Wanderlei Abadio de Oliveira ${ }^{2}$ - André Vilela Komatsu ${ }^{3}$. Marcela Almeida Zequinão ${ }^{4}$ - Beatriz Oliveira Pereira ${ }^{5}$. Simona Carla Silvia Caravita $^{6} \cdot$ Grace Skrzypiec $^{7} \cdot$ Marta Angélica lossi Silva $^{8}$

University of Franca, Franca University, Franca, Brazil

2 Pontifical Catholic University of Campinas, São Paulo, Brazil

3 University of São Paulo, São Paulo, Brazil

4 Santa Catarina State University, Florianópolis, Brazil

5 University of Minho, Braga, Portugal

6 Catholic University of the Sacred Heart, Milan, Italy

7 Flinders University, Adelaide, Australia

8 University of São Paulo, São Paulo, Brazil 